\title{
Evolution of local e-government maturity in Portugal
}

\author{
Gonçalo Paiva Dias \\ Águeda School of Technology and Management / Research \\ Unit on Governance, Competitiveness and Public Policies \\ University of Aveiro \\ Águeda, Portugal \\ gpd@ua.pt
}

\author{
Hélder Gomes \\ Águeda School of Technology and Management / Institute \\ of Electronics and Telematics Engineering of Aveiro \\ University of Aveiro \\ Águeda, Portugal \\ helder.gomes@ua.pt
}

\begin{abstract}
In this article we present the results of a website content analysis of all Portuguese municipalities performed in 2013. A three-dimensional maturity model was used to categorize e-government development. The results are compared with others obtained in 2010 in order to characterize local egovernment evolution in Portugal. The main conclusion of this study is that, although the results of municipalities have globally improved between 2010 and 2013, the gap between municipalities to what respects e-government development is also growing. Indeed, a non-negligible percentage of municipalities worsened their results in this period.
\end{abstract}

Keywords: e-government; local government; maturity; Portugal

\section{INTRODUCTION}

In [1], e-government is defined as "the use of information technology to support government operations, engage citizens, and provide government services". This definition encompasses the use of information technology in multiple aspects of government activity: internal flows of information; government procurement; delivery of information and services; citizen's participation in the public decision making process. When local government is at stake, the definition remains valid and the expression 'local e-government' is usually used $[2,3]$.

In this article, we aim to address the current state and evolution of local e-government maturity in Portugal. To do so, we addressed three different dimensions of e-government as practiced by Portuguese municipalities: government information; service delivery; and citizens' participation. This approach, based on website content analysis, was originally proposed in [4]. To tackle e-government evolution, we compared the empirical data originally presented in that study with new data we collected in 2013.

The first studies to address e-government maturity in Portuguese municipalities were conducted by Santos and Amaral between 1999 and 2007 [5]. In these studies, the authors conducted observations of all Portuguese municipal websites, using a four stage maturity model to assess online service delivery. Two other studies were subsequently published in [6] and [4], relating to data collected in 2010. In the first, the authors made the observation of 239 municipal websites, registering their general characteristics, available information and online maturity of service delivery. In the second, the authors defined and used a multidimensional maturity model to categorize the empirical observation of the websites of all 308 Portuguese municipalities. Other studies relating different aspects of local e-government in Portugal can be found in [7-18]. More information on e-government maturity models can be found in [19-21].

The remaining of this article in organized as follows: in the second section we present the methodology used in the research; in the third section we present the results and discussion; and in the fourth section we present the general conclusions.

\section{METHODOLOGY}

The methodology used in this study was originally proposed and used in [4]. It consists of a website content analysis and the subsequent use of a three-dimensional maturity model to categorize the empirical observations. The three dimensions of the model correspond to three different aspects of the supply side of e-government: access to government information (information); electronic service delivery (services); and participation in public decisions (participation).

In each dimension, development is established using four maturity stages. Tables 1 to 3 show the characteristics that define the maturity stages for each dimension, as proposed in [4].

TABLE I. STAGES FOR THE INFORMATION DIMENSION

\begin{tabular}{|c|l|}
\hline Stage & \multicolumn{1}{c|}{ Observed characteristics } \\
\hline Stage 1 & $\begin{array}{l}\text { The website provides generic information about the } \\
\text { municipality (e.g., address, opening hours, members } \\
\text { of the city council, etc.). }\end{array}$ \\
\hline Stage 2 & $\begin{array}{l}\text { There are public access documents available for } \\
\text { viewing or downloading by the public without prior } \\
\text { authentication (e.g., minutes of city council, plan, } \\
\text { annual budget, etc.) }\end{array}$ \\
\hline Stage 3 & $\begin{array}{l}\text { There is search functionality for text strings in } \\
\text { documents by which you can find information in } \\
\text { publicly available documents identified in the } \\
\text { previous stage. }\end{array}$ \\
\hline Stage 4 & $\begin{array}{l}\text { There is a feature that allows you to parameterize } \\
\text { searches for documents based on their characteristics } \\
\text { (e.g., document type, title, publication date, author) } \\
\text { that works in conjunction with textual search. } \\
\text { Compliance with this stage assumes compliance with } \\
\text { the previous stage. }\end{array}$ \\
\hline
\end{tabular}


TABLE II. STAGES FOR THE SERVICES DIMENSION

\begin{tabular}{|c|l|}
\hline Stage & \multicolumn{1}{c|}{ Observed characteristics } \\
\hline Stage 1 & $\begin{array}{l}\text { The website provides information about the specific } \\
\text { services that are provided by the municipality (e.g., } \\
\text { forms to use, mandatory documents, relevant } \\
\text { regulations, etc.). }\end{array}$ \\
\hline Stage 2 & $\begin{array}{l}\text { The website provides a feature that allows } \\
\text { authenticated citizens to check the status of the } \\
\text { services they applied for. }\end{array}$ \\
\hline Stage 3 & $\begin{array}{l}\text { The website provides a feature that allows citizens to } \\
\text { submit forms electronically, although the } \\
\text { formalization of the requirements may involve a } \\
\text { subsequent physical interaction. }\end{array}$ \\
\hline Stage 4 & $\begin{array}{l}\text { The website provides a feature that allows } \\
\text { authenticated citizens to request and complete at least } \\
\text { one electronic service provided by the city council. } \\
\text { Compliance with this stage assumes completion of } \\
\text { the previous stage. }\end{array}$ \\
\hline
\end{tabular}

TABLE III. STAGES FOR THE PARTICIPATION DIMENSION

\begin{tabular}{|c|l|}
\hline Stage & \multicolumn{1}{c|}{ Observed characteristics } \\
\hline Stage 1 & $\begin{array}{l}\text { The website provides a feature that allows citizens to } \\
\text { submit suggestions and/or complaints, with or } \\
\text { without authentication and/or prior identification. }\end{array}$ \\
\hline Stage 2 & $\begin{array}{l}\text { There is the possibility to participate in opinion polls } \\
\text { and/or discussion groups regarding matters related to } \\
\text { policy areas of the city council, with or without } \\
\text { authentication and/or prior identification. }\end{array}$ \\
\hline Stage 3 & $\begin{array}{l}\text { There is the possibility to participate in processes of } \\
\text { public discussion with mandatory consideration or } \\
\text { response by the city council (e.g., public consultation } \\
\text { of regulations, land development plans, urbanization } \\
\text { plans, etc.). }\end{array}$ \\
\hline Stage 4 & $\begin{array}{l}\text { There is the possibility to contribute to the decision- } \\
\text { making processes of participatory budgets } \\
\text { (government mechanisms of participatory democracy } \\
\text { that allow citizens to influence or decide on public } \\
\text { budgets). }\end{array}$ \\
\hline
\end{tabular}

The websites of all 308 Portuguese municipalities were observed and categorized. The field work took place during May and October, 2013. The observations were made by several different teams, each responsible for 28 to 70 municipalities, depending on the number of team elements. Each team was formed by 2 to 5 undergraduate and postgraduate students. The municipalities were randomly assigned to each team. Each team filled out an electronic form by pasting the URL of the pages where relevant characteristics were observed. Data was later downloaded into a single database to calculate global results.

For calculation purposes, the completion of each maturity stage of each dimension was valued 1 point. Thus, each municipality was ranked between 0 and 4 for each dimension. For simplicity, the resulting discrete variables were named information, services and participation, matching the homonymous dimensions. A fourth discrete variable named development was computed by adding the scores of each municipality in the three dimensions.
The results were then compared with the results obtained by [4] in 2010. This was possible because the same methodology was used in both studies. The results obtained in 2013 and its comparison with the results obtained in 2010 are presented and discussed in the next section. For some of the analysis, the municipalities were aggregated by NUTS III (third level of Nomenclature of Units for Territorial Statistics geocode standard for referencing the subdivisions of countries for statistical purposes in the European Union).

\section{RESULTS AND DISCUSSION}

Table IV presents the number and percentage of municipalities that achieved each of the maturity stages in each dimension, in 2013. The variation of these figures since 2010 is then presented in Table $\mathrm{V}$.

From the observation of these tables it is apparent that municipalities tend to privilege development in the information dimension in detriment of the services and participation dimensions. This corroborates the results obtained by [4] in 2010. Generally, results have improved for every dimension between 2010 and 2013. However, a closer look allows us to conclude that not all municipalities have improved. This is apparent from the fact that, for every dimension, although the percentage of municipalities that achieve the upper maturity stages increases significantly, the percentage of municipalities that achieve the lower stages decreases. So, there are a significant number of municipalities that improve their results whereas there are also a significant number of municipalities that worsen their results. That is, the gap between municipalities increases. This can be seen clearly in Table VI.

TABLE IV. NUMBER AND PERCENTAGE OF MUNICIPALITIES BY MATURITY STAGE, IN 2013

\begin{tabular}{|c|c|c|c|c|c|c|c|c|}
\hline Dimension & \multicolumn{2}{|c|}{ Stage 1 } & \multicolumn{2}{c|}{ Stage 2 } & \multicolumn{2}{c|}{ Stage 3 } & \multicolumn{2}{c|}{ Stage 4 } \\
\hline Information & 304 & $99 \%$ & 291 & $94 \%$ & 157 & $51 \%$ & 99 & $32 \%$ \\
\hline Services & 251 & $81 \%$ & 69 & $22 \%$ & 94 & $31 \%$ & 52 & $17 \%$ \\
\hline Participation & 195 & $63 \%$ & 39 & $13 \%$ & 45 & $15 \%$ & 16 & $5,2 \%$ \\
\hline
\end{tabular}

TABLE V. VARIATION OF MUNICIPALITIES BY MATURITY STAGE, BETWEEN 2010 AND 2013

\begin{tabular}{|c|c|c|c|c|c|c|c|c|}
\hline \multirow{2}{*}{ Dimension } & \multicolumn{2}{|c|}{ Stage 1 } & \multicolumn{2}{c|}{ Stage 2 } & \multicolumn{2}{c|}{ Stage 3 } & \multicolumn{2}{c|}{ Stage 4 } \\
\cline { 2 - 9 } & var. $^{\mathrm{a}}$ & p.p. $^{\mathrm{b}}$ & var. $^{\mathrm{a}}$ & p.p. $^{\mathrm{b}}$ & var. $^{\mathrm{a}}$ & p.p. $^{\mathrm{b}}$ & var. $^{\mathrm{a}}$ & p.p. $^{\mathrm{b}}$ \\
\hline Information & -4 & -1.3 & -10 & -3.2 & -52 & -16.9 & +86 & +27.9 \\
\hline Services & +1 & +0.3 & -3 & -1.0 & +37 & +12.0 & +41 & +13.3 \\
\hline Participation & -19 & -6.2 & -21 & -6.8 & +22 & +7.1 & +7 & +2.3 \\
\hline
\end{tabular}

TABLE VI. MUNICIPALITES THAT IMPROVED, MAINTAINED AND WORSENDED THEIR SCORE BETWEEN 2010 AND 2013, BY DIMENSION

\begin{tabular}{|c|c|c|c|}
\hline Dimension & Improved & Maintained & Worsened \\
\hline Information & $33 \%$ & $35 \%$ & $32 \%$ \\
\hline Services & $36 \%$ & $41 \%$ & $22 \%$ \\
\hline Participation & $26 \%$ & $44 \%$ & $30 \%$ \\
\hline
\end{tabular}


Table VII shows the mean, median and standard deviation for the discrete variables information, services and participation, that correspond to the homonymous dimensions, and also for the global development variable, as published in [4]. Table VIII shows the same results for the 2013 sample. From the comparison of the two tables it is apparent that while the median is the same for every variable, the mean always increases. This corroborates the previous conclusion that there is a noticeable improvement in global results. Nevertheless, because the standard deviation also increases for the four variables, and as stated before, there is a bigger gap between municipalities.

TABLE VII. MEAN, MEDIAN, STANDAR DEVIATION AND RANGE FOR EACH DIMENSION, IN 2010

\begin{tabular}{|c|c|c|c|c|}
\hline Dimension & Mean & Median & Std. dev. & Range \\
\hline Information & 2.70 & 3 & 0.58 & $1-4$ \\
\hline Services & 1.27 & 1 & 0.95 & $0-4$ \\
\hline Participation & 1.00 & 1 & 0.73 & $0-4$ \\
\hline Development & 4.97 & 5 & 1.68 & $1-10$ \\
\hline
\end{tabular}

TABLE VIII. MEAN, MEDIAN, STANDAR DEVIATION AND RANGE FOR EACH DIMENSION, IN 2013

\begin{tabular}{|c|c|c|c|c|}
\hline Dimension & Mean & Median & Std. dev. & Range \\
\hline Information & 2.77 & 3 & 0.95 & $0-4$ \\
\hline Services & 1.51 & 1 & 1.17 & $0-4$ \\
\hline Participation & 0.95 & 1 & 0.83 & $0-4$ \\
\hline Development & 5.22 & 5 & 1.97 & $1-11$ \\
\hline
\end{tabular}

Figure 1 depicts the median results for the development variable by NUTS III, in 2013. Although means hide differences inside regions, it is very visible in the map the asymmetry that exists between different regions for this variable. The best results (all dimensions considered) are obtained by the Ave (Av) region, with a mean of 7.3. The worst results are obtained by the Baixo Alentejo (BA) region, with a mean of 3.92

The means for each dimension are depicted as a radial graph in Figure 2. In the graph NUST IIII are ordered, starting from the top using clockwise direction, by their mean in the development variable. It can be seen that the global score of the Ave (Av) region is the result of better than the average results in the services and the participation dimensions. As opposed, the low global score of the Baixo Alentejo (BA) region is due to low scores in all the three dimensions.

In Figure 3 it is depicted the mean variation of the development variable between 2010 and 2013 by NUTS III. In the map it can be observed that improvement is also asymmetric between different regions. Eight regions have worsened their mean results. Those include both regions with high means as regions with low means.

The means variations for each dimension by NUTS III are depicted as a radial graph in in Figure 4 . The high asymmetry of variation is also visible in this gragh.

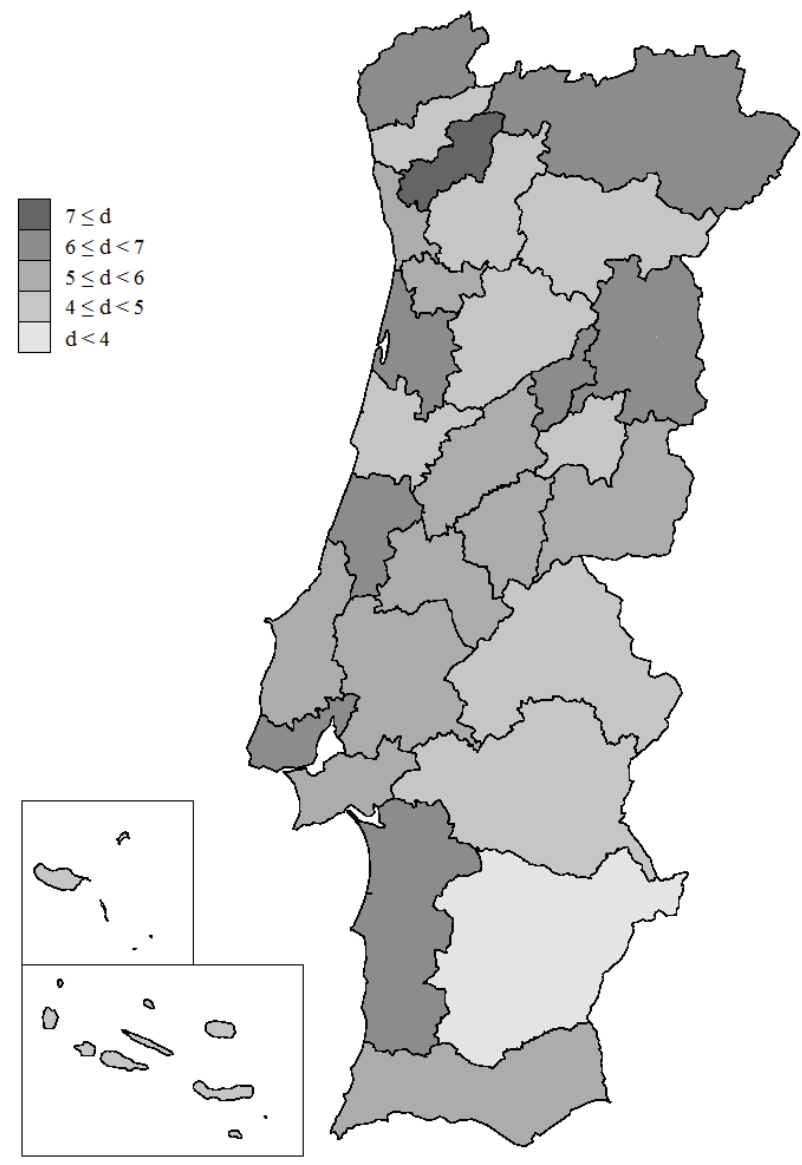

Figure 1. Representation in the map of Portugal of the mean of development by NUTS III, in 2013

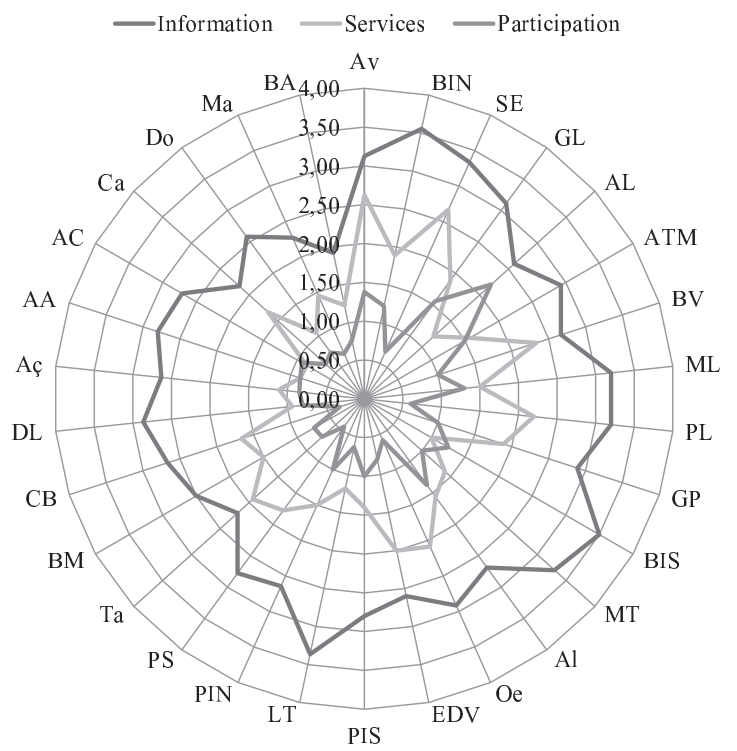

NUTS III codification: Av - Ave; BIN - Beira Interior Norte; SE - Serra da Estrela; GL - Grande Lisboa; AL - Alentejo Litoral; ATM-Alto Trás-os-Montes; BV - Baixo Vouga; ML - Minho-Lima; PL - Pinhal Litoral, GP - Grande Porto, BIS - Beira Interor Sul, MT - Medo Tejo, Al - Algarve, Oe - Oeste, EDV Pent De eninsula de Seutbal, Ta - Tamega, BM - Baixo Mondego; CB - Cova da Beira, DL - Dão-Lafões; A A̧̧ores; AA - Alto Alentejo; AC - Alentejo Central; Ca - Cávado; Do - Douro; Ma - Madeira; BA Baixo Alentejo.

Figure 2. Means of information, services and participation by NUTS III, in 2013. 


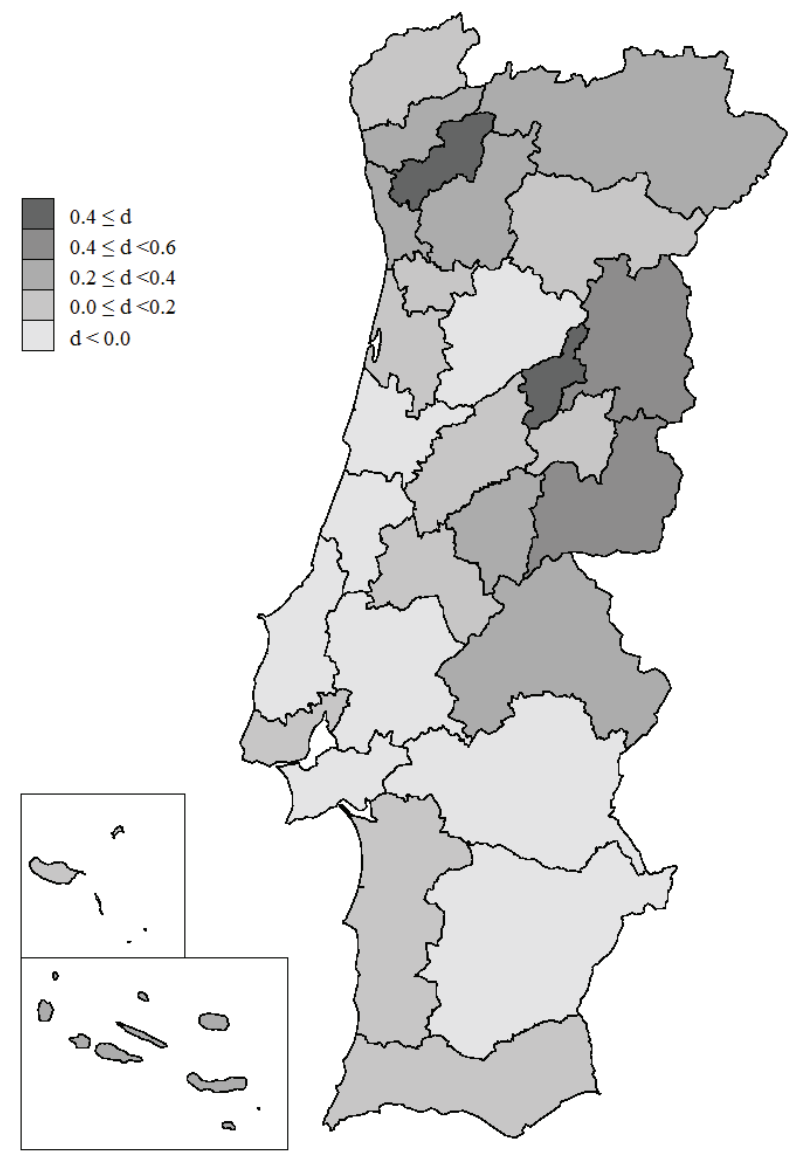

Figure 3. Representation in the map of Portugal of the variation of the mean of development by NUTS III, between 2010 and 2013.

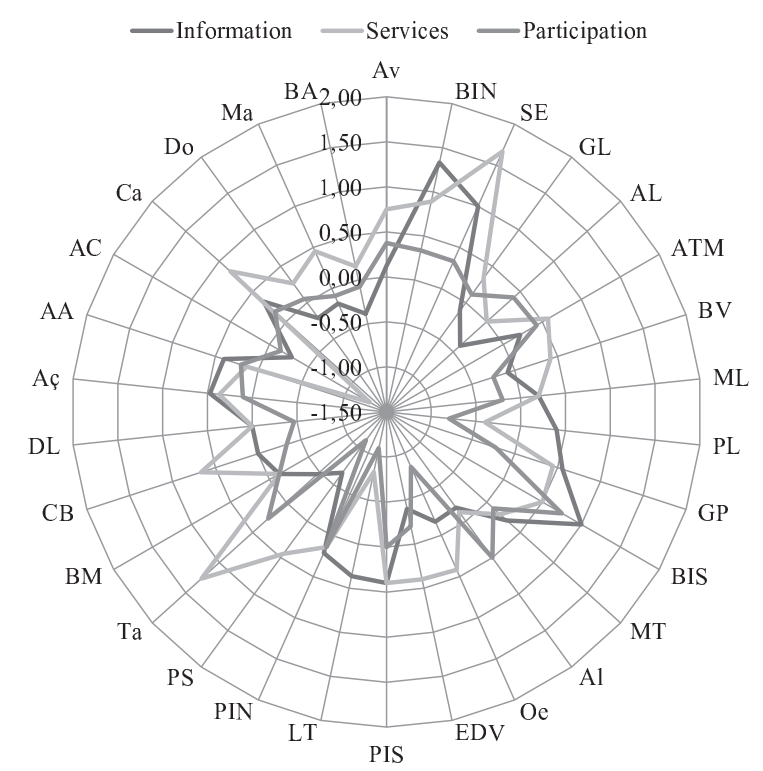

NUTS III codification: Av - Ave; BIN - Beira Interior Norte; SE - Serra da Estrela; GL - Grande Lisboa; AL - Alentejo Litoral; ATM-Alto Trás-os-Montes; BV - Baixo Vouga; ML - Minho-Lima; PL - Pinhal Litoral; GP - Grande Porto; BIS - Beira Interior Sul; MT - Médio Tejo; Al - Algarve; Oe - Oeste; EDV Entre Douro e Vouga; PIS - Pinhal Interior Sul; LT - Lezíria do Tejo; PIN - Pinhal Interior Norte; PS Península de Setúbal; Ta - Tâmega; BM - Baixo Mondego; CB - Cova da Beira; DL - Dão-Lafões; Aç Açores; AA - Alto Alentejo; AC - Alentejo Central; Ca - Cávado; Do - Douro; Ma - Madeira; BA Baixo Alentejo.

Figure 4. Variation of the mean of information, services and participation by NUTS III, between 2010 and 2013

\section{CONCLUSIONS}

In this article, we presented the current state of local egovernment maturity in Portugal. Three different dimensions of e-government supply were studied: government information; service delivery; and citizens' participation. A methodology originally proposed in [4] was used. The results we obtained in 2013 were compared with the results obtained in 2010 by that study.

Our results corroborate part of the conclusions previously observed in [4]: local e-government in Portugal remains substantially underdeveloped, despite three years have passed; and municipalities seem to continue to favor the development of simpler facilities (publication of documents online, textbased searches, information on services, reception of complaints and suggestions) in detriment of more complex ones (query of service provision, form submission and complete online transactions) or that may have more serious political or administrative implications (opinion polls, free discussion, procedures for public discussion and participatory budgeting). To this respect, its worth mentioning that the number of municipalities that allow citizens to submit suggestions or complaints or to participate in opinion polls or discussion groups has significantly decreased.

To what concerns evolution between 2010 and 2013, we have observed that, although noticeable improvements exist in every dimension, the gap between municipalities has also increased. Depending on the dimension considered, between $26 \%$ and $36 \%$ of the municipalities have improved their results while between $22 \%$ and $32 \%$ have worsened them.

Although our results are interesting and novel, several questions remain unanswered. The most relevant one respects to the reasons that may cause the growing gap between municipalities in terms of e-government development. Possible courses of action to investigate this question include correlating our results with municipal socio-economic factors and further analyze the territorial distribution of results and their evolution. Case studies may also prove useful to this respect, namely to identify if there is an impact caused by the absence of development programs for local e-government in the past years, that may significantly impact the small and medium municipalities witch also have fewer resources.

\section{ACKNOWLEDGMENT}

The authors acknowledge the students enrolled in the courses 'Electronic Government' and 'Digital Government' of the School of Technology and Management of Águeda and the University of Aveiro, 2013, by their involvement in the field work.

\section{REFERENCES}

[1] M. Cook, M. LaVigne, C. Pagano, S. Dawes and T. Pardo, Making a Case for Local e-Government. Albany, NY: Center for Technology in Government, 2002.

[2] K. D. Edmiston, "State and local e-government - prospects and challenges," American Review of Public Administration, vol. 33, pp. 10 45, March 2003. 
[3] Y. C. Chen, YC and J. Gant, J (Gant, J), "Transforming local egovernment services: the use of application service providers," Government Information Quarterly, vol. 18, pp. 343-355, 2001.

[4] G. P. Dias and M. Costa, "Significant socio-economic factors for local egovernment development in Portugal," Eletronic Government, An International Journal, vol. 10, pp. 284-309, 2013.

[5] L. Santos and L. Amaral, Presença na Internet das câmaras municipais portuguesas em 2007, estudo sobre local e-government em Portugal. Guimarães, Portugal: Gávea, Universidade do Minho, 2007.

[6] G. P. Dias, "Local e-government information and service delivery, a survey of municipal websites in Portugal," Sistemas e Tecnologias de Informação, Proceedings of the 6th Iberian Information Systems and Technologies Conference (CISTI' 2011), 15-18 June, Chaves. Rio Tinto, Portugal: AISTI, 2011, pp. 98-103.

[7] M. Tavares, M., "The use of cybergenres as a communication and knowledge management process in local government," Proceedings of the 26th Annual ACM International Conference on Design of Communication, 22-24 September, 2008, Lisbon. New York: ACM, 2008, pp.283-284.

[8] G. P. Dias, and J. M. Moreira, "Transparency, corruption and ICT (illustrated with Portuguese cases)," in A. Vaccaro, H. Horta and P. Madsen (Eds.): Transparency, and Information and Communication Technology: Social Responsibility and Accountability in Business and Education. Charlottesville, VA: Philosophy Documentation Center, 2008, pp.151-160.

[9] M. J. Simões and D. Santos, "Challenges in the digital cities and regions in Portugal," in P. Cunningham and M. Cunningham (Eds.), Collaboration and Knowledge Economy: Issues, Applications, Case Studies, Information and Communication Technologies and the Knowledge Economy Book Series. Amsterdam, Netherlands: IOS Press, Vol. 5, 2008, pp.546-554.

[10] R. Gomes and J. Ribeiro, "Use of Web Services in e-government information systems, a case study', Proceedings of the 2009 International Conference on Information Management and Engineering, 3-5 April, 2009, Kuala Lumpur. Los Alamitos, CA: IEEE Computer Society, 2009, pp.475-480.

[11] G. P. Dias and T. Narciso, "Analysis of the potential for organizational interoperability improvement in local government," Sistemas y Tecnologias de Informacion, Proceedings of the 5th Iberian Conference on Information Systems and Technologies (CISTI' 2010), 16-19 June, 2010, Santiago Compostela. Rio Tinto, Portugal: AISTI, Vol. 1, 2010, pp.167-172.
[12] M. R. Rodrigues, G. P. Dias and A. Teixeira, "Automatic extraction and representation of geographic entities in eGovernment," Sistemas y Tecnologias de Informacion, Proceedings of the 5th Iberian Conference on Information Systems and Technologies (CISTI' 2010), 16-19 June, 2010, Santiago Compostela. Rio Tinto, Portugal: AISTI, Vol. 1, 2010, pp. 160-163.

[13] A. C. Sanz, J. C. Neves and J. N. Valente, "A conceptual model of elocal government," Sistemas y Tecnologias de Informacion, Proceedings of the 5th Iberian Conference on Information Systems and Technologies (CISTI' 2010), 16-19 June, 2010, Santiago Compostela. Rio Tinto, Portugal: AISTI, Vol. 2, 2010, pp.123-127.

[14] C. Aleixo, M. Nunes and P. Isaias, "Usability and digital inclusion: standards and guidelines," International Journal of Public Administration, Vol. 35, No. 3, pp.221-239, 2012.

[15] F. B. Almeida and P. R. P. Tomé, "e-Government local analysis and evaluation of municipalities in the district of Viseu," Sistemas y Tecnologias de Informacion, Porceedings of the $7^{\text {th }}$ Iberian Conference on Information Systems and Technologies (CISTI' 2012), 20-23 June, 2012, Madrid. Rio Tinto, Portugal: AISTI, 2012, pp. 253-258.

[16] G. P. Dias, H. Gomes and A. Zúquete, "Privacy policies in Web sites of Portuguese municipalities: an empirical study," in A. Rocha, A. M. Correia and T. Wilson (Eds.), Advances in Information Systems and Technologies, Advances in Intelligent Systems and Computing Series. Berlin - Heidelberg: Springer, 2013, pp. 87-96.

[17] P. Santos, A. I. Melo and G. P. Dias, "Administrative modernization and e-government: the case of Águeda," Sistemas e Tecnologias de Informação, Proceedings of the $8^{\text {th }}$ Iberian Iberian Conference on Information Systems and Technologies (CISTI' 2013), 19-22 June, Lisbon. Rio Tinto, Portugal: AISTI, Vol. I, 2012, pp. 782-787.

[18] O. Fedotova, L. Teixeira and H. Alvelos, "E-participation in Portuguese local governments: evaluation of deployment and adherence of web 2.0 technologies," Eletronic Government, An International Journal, vol. 10, pp. 361-379, 2013.

[19] K. Layne and J. Lee, "Developing fully functional E-government: A four stage model," Government information quarterly, Vol. 18, pp. 122-136, 2001 .

[20] K. V. Andersen and H. Z. Henriksen, "E-government maturity models: extension of the Layne and Lee model," Government Information Quarterly, Vol. 23, pp. 236-248, 2006.

[21] G. P. Dias, "Q-Model: um modelo bidimensional de maturidade para o e-government," RISTI - Revista Ibérica de Sistemas e Tecnologias de Informação, Vol. 7, pp. 33-46, 2011. 